\title{
Spleen Histopathological Study of Mice (Mus musculus) Infected with Plasmodium berghei After Treatment with Malacca Leaves extract (Phyllantus emblica)
}

\author{
Amalia Sutriana $^{1 *}$, Rasmaidar ${ }^{1}$, Nuzul Asmilia ${ }^{2}$, Cut Nila Thasmi ${ }^{3}$, Dwinna Aliza ${ }^{4}$, \\ Wahid Muharram 5 \\ ${ }^{1}$ Laboratory of Pharmacology, Faculty of Veterinary Medicine, Universitas Syiah Kuala, Banda Aceh, Indonesia \\ ${ }^{2}$ Laboratory of Clinic, Faculty of Veterinary Medicine, Universitas Syiah Kuala, Banda Aceh, Indonesia \\ ${ }^{3}$ Laboratory of Reproduction, Faculty of Veterinary Medicine, Universitas Syiah Kuala, Banda Aceh, Indonesia \\ ${ }^{4}$ Laboratory of Pathology, Faculty of Veterinary Medicine, Universitas Syiah Kuala, Banda Aceh, Indonesia \\ ${ }^{5}$ Faculty of Veterinary Medicine, Universitas Syiah Kuala, Banda Aceh, Indonesia \\ *Corresponding author. Email: amalia sutriana@unsyah.ac.id
}

\begin{abstract}
This study aimed to evaluate the effect of ethanolic extract of malacca leaves (Phyllantus emblica) on histopathology of mice (Mus musculus) spleen infected with Plasmodium berghei (P. berghei). This study used 15 male Balb/c strain mice aged 2 months, allotted into 5 treatment groups. The mice in group 1 (P0) were infected with $P$. berghei without administration of Malacca leaves extract, while the mice in group 2 (P1) were infected with $P$. berghei and treated with $5 \mathrm{mg} / \mathrm{kg} \mathrm{BW}$ of chloroquine. The mice in group $3(\mathrm{P} 2), 4(\mathrm{P} 3)$, and 5 (P4) were infected with P. berghei and treated with Malacca leaves extract at doses of 100,300 , and $600 \mathrm{mg} / \mathrm{kg} \mathrm{BW}$, respectively. At day $7^{\text {th }}$, all mice were sacrificed, then the spleen were collected for histopathological examination. The observation was carried out on the hemosiderin accumulation, lymphocyte depletion, hemorrhage, and megakaryocyte cells. Data were analyzed using one way analysis of variance (ANOVA). The results showed that the amount of hemosiderin, lymphocyte depletion, and hemorrhage decreased in mice given Malacca leaves extract compared to those in the negative control. In conclusion, the administration of ethanolic extract of malacca leaves reduce the damage of mice spleen due to P. berghei infection
\end{abstract}

Keywords: Malacca leaves extract, spleen, mice, Plasmodium berghei

\section{INTRODUCTION}

Malaria remains as a life threatening disease and poses a great economic and social problem to society both in tropical and sub-tropical areas [1]. Malaria is caused by infection with parasites belong to the genus Plasmodium [2]. Plasmodium is a blood protozoan parasite that requires two alternative hosts, mosquito and vertebrate host, in completing its life cycle. In the mosquito, Plasmodium undergoes an exogenous sexual phase which is characterized by development of zygote to become sporozoite. Then, when the Anopheles mosquito bites a vertebrate host, the sporozoites presents in the mosquito salivary duct ejected and will enter the circulatory system and infect the vertebrate host [1].
One of species in the genus Plasmodium that causes malaria in rodents is Plasmodium berghei [3]. Plasmodium berghei has similar basic biological properties to the Plasmodium which infects humans including morphology, life cycle, and genetic. The clinical presentation of malaria infection often reflects a certain degree of spleen and liver damage. One of the specific pathological alterations is the enlargement of spleen and liver due to the large number of erythrocytes infected with Plasmodium berghei and deposition of lymphocytes and macrophage cells in the spleen and liver [4].

The spleen is a reticuloendothelial organ which is the site for the formation of activated lymphocytes and antibodies and contains many macrophages. The close contact between these cells in the blood circulation is very 
influential in the body's defense system against microorganisms, foreign particles, abnormal cells, and in secreting old or abnormal erythrocytes. Spleen organ is crucial in terms of confrontation of immune cells and foreign substances [5]. Histopathologically, the spleens of animals infected with Plasmodium berghei showed hyperemia, hemosiderin, red pulp depletion, and megalokaryocyte cells [6].

The emergence of Plasmodium resistance to available antimalarial drugs has prompted research to seek new and effective malaria treatment alternatives. One of the efforts to find alternative malaria treatment is using medicinal plants that can reduce damage to several organs such as the spleen due to plasmodium infection [6].

Malacca plant (Pyllanthus emblica) is small or medium size plant with greenish-grey stems and greenishyellow flowers [7]. Empirically, in Ayurvedic medicine, Malacca tree is used for treatment of diarrhoea, flu, fever, diuretic, laxative and as a hair tonic. Several chemical compounds contained in the ethanol extract of the Malacca fruit and leaves include alkaloids, essential oils, glycerolipids, carbohydrates, phenols, tannins, lignins, saponins, flavonoids, and terpenoids [8]

Polyphenols (tannins) are a very complex component of organic substances, which play a role in precipitating proteins and repair the damaged cells. Teng et al. [9] stated that the flavonoid content in the Malacca plant was proven effective in constraining Plasmodium, as well as having bioactivity to decrease the levels of Plasmodium berghei parasitemia in mice. Although the Malacca plant has been shown to reduce levels of Plasmodium berghei parasitemia in mice, its effect on spleen organ has not been fully studied. Therefore, this study aims to determine the effect of ethanol extract of Malacca leaves (Phyllanthus Emblica) on the spleen histopathological changes of mice (Mus musculus) infected with Plasmodium berghei.

\section{MATERIALS AND METHODS}

\subsection{Plasmodium berghei Infection on Mice}

This study was designed using a completely randomized design (CRD) with 5 treatments and each treatment consisted of 3 replications. The mice in treatment $1(\mathrm{P} 0)$ were injected with Plasmodium berghei and considered as negative control, while the mice in treatment 2 (P1, positive control) were infected with Plasmodium berghei and given $5 \mathrm{mg} / \mathrm{kg}$ of chloroquine. The mice in treatment $3(\mathrm{P} 2), 4(\mathrm{P} 3)$, and $5(\mathrm{P} 4)$ were infected with Plasmodium berghei and given ethanol extract of Malacca leaves with a single dose of 100, 300, and, $600 \mathrm{mg} / \mathrm{kg} \mathrm{BW}$, respectively. These mice were infected intraperitoneally using a tuberculin syringe with $1 \times 10^{5}$ Plasmodium berghei, then, the extract was given orally using a stomach tube for 4 consecutive days. After 7 days, the mice were sacrificed and the spleen organs were taken for histopathological examination. Spleen organs that have been collected are fixed in $10 \% \mathrm{NBF}$ solution.

\subsection{Histological Processing and Staining of Spleen Tissue}

The spleens were fixed in $10 \%$ NBF solution for 24 hours with the ratio between the organs and the solution is $1: 10$. The samples were then dehydrated using alcohol with graded concentrations of $70 \%, 80 \%, 90 \%, 96 \%$, absolute alcohol I and II with an interval of 2 hours for each concentration. Then, the clearing was done using xylol I and II for 2 hours, followed by the infiltration process using liquid paraffin solutions I and II for 2 hours in an oven with a temperature of $60{ }^{\circ} \mathrm{C}$. The embedding process was carried out by soaking the sample in a paraffin block and sectioning using a rotary microtome with a thickness of 5-6 $\mu \mathrm{m}$. The tissues were stretched in the water at temperature of $50{ }^{\circ} \mathrm{C}$, and then fixed on a glass object, dried in a slide warmer for 24 hours at $37^{\circ} \mathrm{C}$ [9].

Prior to HE staining, the samples were deparaffinized in xylol I and II for 2 minutes, then rehydration with $96 \%$ and $90 \%$ alcohol and water for 2 minutes. The sample was stained with Hematoxylin-Eosin solution, immersed in water, acid alcohol, and distilled water. Eosin staining was carried out for 1 minute and soaked with water until clean. The dehydration process used 96\% alcohol, absolute alcohol I and II, and xylol I and II. Histopathological observation was carried out under light microscope with a magnification of $10 \times 40$ in five fields of view $(5 \mathrm{~mm} \times$ $5 \mathrm{~mm}$ ). The observation was carried out on the presence of hemosiderin accumulation, lymphocyte depletion, hemorrhage, and the presence of megakaryocyte cells.

\subsection{Data Analysis}

Data were analyzed using analysis of variance (ANOVA).

\section{RESULTS AND DISCUSSION}

The histopathological changes of mice spleen in the five treatment groups can be seen in Figure 1. The histopathological observations indicate changes in the form of hemosiderin accumulation, lymphocytedepletion, hemorrhage, and the presence of megakaryocyte cells at different level.

The level of histopathological changes in the spleen was then scored according to Gimeno et al., [11] and analyzed statistically. The statistical analysis of histopathological changes in mice spleen is presented in Table 1 . 

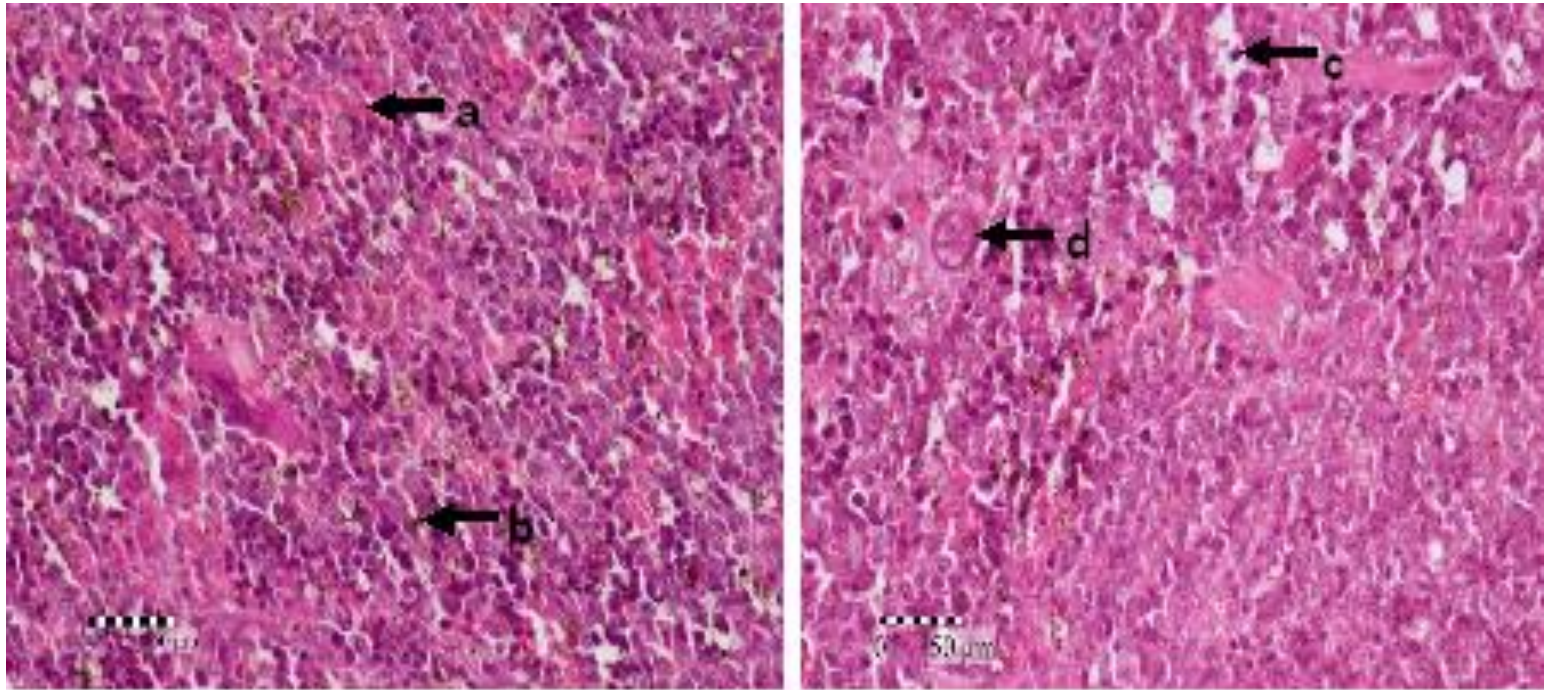

Figure 1 Histopathological change of spleen of mice (Mus musculus) infected with Plasmodium berghei and given ethanol extract of Malacca leaf (Phyllanthus emblica); Hemorrhage (a), Hemosiderin (b), Depletion of lymphocytes (c), megakaryocytes (d). (HE, 400x).

Table 1. Average number of cells that experienced histopathological changes in the spleens of mice infected with Plasmodium berghei and given ethanol extract of malacca leaves

\begin{tabular}{|c|c|c|c|c|}
\hline Treatment & Hemosiderin & Depletion of Limphocytes & Hemorrhage & Megakaryocytes \\
\hline P0 & $35.67 \pm 2.08^{c}$ & $52.00 \pm 10.44^{c}$ & $30.33 \pm 9.71^{b}$ & $1.67 \pm 0.58^{a}$ \\
\hline P1 & $29.33 \pm 3.79^{b}$ & $44.00 \pm 6.00^{b c}$ & $25.33 \pm 4.16^{a b}$ & $1.33 \pm 1.53^{a}$ \\
\hline P2 & $28.33 \pm 3.22^{b}$ & $46.67 \pm 4.04^{c}$ & $17.67 \pm 6.81^{a}$ & $1.00 \pm 1.00^{a}$ \\
\hline P3 & $16.00 \pm 3.00^{a}$ & $23.33 \pm 6.03^{a}$ & $21,67 \pm 0.58^{a b}$ & $2.33 \pm 1.53^{a}$ \\
\hline P4 & $25.67 \pm 4.16^{b}$ & $31.67 \pm 6.43^{a b}$ & $24.00 \pm 4.36^{a b}$ & $0.33 \pm 0.58^{a}$ \\
\hline
\end{tabular}

Information :

a b c Different superscripts in the same column indicate significant differences $(\mathrm{P}<0.05)$.

P0: Negative control (infected with Plasmodium berghei without giving ethanol extract of Malacca leaves).

P1: Positive control (infected with Plasmodium berghei and given chloroquin $5 \mathrm{mg} / \mathrm{kg} \mathrm{BW}$ ).

P2: Infected with Plasmodium berghei and given ethanol extract of Malacca leaves at dose of $100 \mathrm{mg} / \mathrm{kg} \mathrm{BW}$.

P3: Infected with Plasmodium berghei and given ethanol extract of Malacca leaves at dose of $300 \mathrm{mg} / \mathrm{kg} \mathrm{BW}$.

P4: Infected with Plasmodium berghei and given ethanol extract of Malacca leaves at dose of $600 \mathrm{mg} / \mathrm{kg} \mathrm{BW}$.

Table 1 showed that the group given the ethanol extract of Malacca leaves had a lower hemosiderin value and was significantly different $(\mathrm{P}<0.05)$ when compared to the negative control group (P0). The lowest number was found in the P3 treatment group with a dose of $300 \mathrm{mg} / \mathrm{kg}$ of Malacca leaf extract and significantly different $(\mathrm{P}<0.05)$ compared to all treatment groups. Hemosiderin is a protein or blood amino acid that is formed when red blood cells are damaged [6]. Hemosiderin accumulation occurs in the spleen tissue due to the pigment hemozoin produced by Plasmodium causing protein or amino acids in red blood cells to break down and turn brown [12]. The lowest reduction in the amount of hemosiderin was observed in P3 (mice given ethanol extract at a dose of $300 \mathrm{mg} / \mathrm{kg} \mathrm{bb}$ ). The reduction was assumed due to the presence of terpenoid compounds that can inhibit hemosiderin biosynthesis [13]. The highest average amount of hemosiderin was found in P0 (negative control).

The results of this study also showed the presence of lymphocyte depletion in the spleen tissue in each treatment, and the highest number was found in the P0 (without giving ethanol extract of Malacca leaves) (Table 1). According to Amin and Qubih [14], lymphocyte depletion in the spleen is marked by a decrease in lymphocyte cells. Depletion of lymphocytes in spleen tissue is usually an acute inflammatory response due to the migration of heterophils and lymphocytes from the spleen to the site of inflammation due to stimulation of 
inflammatory mediators [15]. The tendency of decreasing lymphocyte depletion in this study indicated an improvement in the spleens of mice given chloroquine and ethanol extract of Malacca leaves.

Hemorrhage was found in the spleen tissue in each treatment (Figure 1) with varying amounts (Table 1) due to Plasmodium berghei infection. Similarly, Intan et al. [6] reported the presence of hemorrhage in spleen tissue of mice infected with Plasmodium berghei. The administration of ethanol extract from Malacca leaves with different doses reduced the amount of hemorrhage in the spleen and the lowest amount was found in treatment $\mathrm{P} 2$ which was significantly different $(\mathrm{P}<0.05)$ compared to the negative control group (P0). Hemorrhage is a loss of blood from blood vessels (extravasation) into the body cavity or into the surrounding tissues. Hemorrhage is the later stage of congestion that occurs due to a loss of the ability to block blood which results in the blood vessels becoming stretched and eventually ruptured [16]. According to Maung and Than [17], during Plasmodium berghei infection, extravasation of red blood cells is not only due to the rupture of blood vessels but also an increase in vascular permeability which results in the release of red blood cells, both uninfected red blood cells and infected with trophozoite.

The observation also found megakaryocyte cells in each treatment, but the values were not significantly different $(\mathrm{P}<0.05)$ among the treatment groups. Megakaryocyte cells in the spleen tissue function as phagocytosis of red blood cells infected by Plasmodium berghei [18]. Megakaryocyte cells also have the ability to engulf the hemozoin pigment produced by Plasmodium berghei. Hemozoin is a parasites detoxification product which inhibits monocyte cells and initiates macrophages to release cytokines which have an effect on inhibition of erythropoietic processes $[19,20]$

The initial response of the body in eliminating Plasmodium berghei is the interaction carried out by macrophages, neutrophils and other phagocytic cells. Interferon $-\gamma(\mathrm{IFN}-\gamma)$ produced by $\mathrm{T}$ lymphocytes will initiate the activity of macrophage cells in destroying Plasmodium berghei by means of oxygen radicals and nitrogen radicals. Oxygen radicals include anion superoxide $(\mathrm{O} 2)$, hydroxyl radicals $(\mathrm{OH})$, hydrogen peroxide (H2O2), while nitrogen radicals include nitric oxide through the inducible Nitric Oxide Synthase (iNOS) [21].

The spleen is the main immune response organ which plays a role in filtering red blood cells infected with parasites and is also the place for the regulation of the immune system [22]. According to Muladi et al. [23], a spleen is a place of destruction and storage of platelets. Due to the infection of erythrocytes by Plasmodium berghei, erythrocytes with parasites bind young and mature erythrocytes and platelets and will trigger the destruction by macrophages in the spleen including the healthy erythrocytes and platelets. As a consequence, it will cause a blockage in the spleen and in turn causing an enlargement of the spleen.

\section{CONCLUSION}

It was concluded that the administration of ethanolic extract of malacca leaves is able to reduce the damage of mice spleen due to $P$. berghei infection.

\section{AUTHORS' CONTRIBUTIONS}

The research was designed by AS and RR. The field work was conducted by NA, CNT, DA and WM. The manuscript was written by AS, DA, and NA.

\section{REFERENCES}

[1] T.R.I Putra, Malaria dan permasalahannya. Jurnal Kedokteran Syiah Kuala, 2011, 11(2): 103-114.

[2] R. Muti'ah, L. Enggar, S. Winarsih, S. Soemarko, D. Simamora, Kombinasi ekstrak batang talikuning dan artemisin sebagai obat antimalaria terhadap plasmodium berghei. jurnal kedokteran brawijaya, 26(1) (2010) 8-13.

[3] Darlina, T. Kisnanto, A. Fauzan, Respons hematopoitik mencit yang diinfeksi dengan Plasmodium berghei stadium eritrositik iradiasi gamma. Jurnal Sains dan Teknologi Nuklir Indonesia, 13(2) (2012) 85-94.

[4] A. Nugroho, P.N. Harijanto, E.A. Datau, Imunologi Malaria Malaria: Epidemiologi, Patogenesis, Manifestasi Klinis Dan Penanganan. Penerbit Buku Kedokteran (EGC), Jakarta, 2003.

[5] C. Matheos, P. Lintong, C. Kairupan, Gambaran histologik jaringan limpa tikus putih (Rattus norvegicus) yang diinfeksi Eschericia coli dan diberi madu. Jurnal e-Biomedik, 1(2) (2013) 961-965.

[6] R.I. Intan, T.W. Lestari, Y. Sani, Studi histopatologi pasca pemberian ekstrak campuran kulit batang pulai (Alstonia scholaris L. R. Br.) dan meniran (Phyllanthus niruri L.) pada mencit terinfeksi Plasmodium berghei. Jurnal Kedokteran Yarsi, 25 (1) (2017) 10-22.

[7] D.A. Dhale, Pharmacognostic evaluation of Phyllantus emblica Linn (Euphorbiaceae). Int. J. Pharma Biol. Sci., 3(3) (2012) 210-217. 
[8] N.I. Fauzi, S.A. Ardiansyah, S. Hidayat, Skrining mekanisme kerja daun malaka (phyllanthus emblica l.) sebagai antidiabetes. tropical medicine conference series, 1 (2018) 106-110.

[9] C.W. Teng, K.H. Halin, S. Ruwanaruk, L.K. Hok, Medicinal plants and Malaria: Aplications, Trends, and Prospects. CRC Press, Boca Raton, 2016.

[10] J.A. Kiernan, Histological Histochemical methods, Theory and practice, Pergamon Press, Oxford, 1990.

[11] I.M. Gimeno, M. Enrique, M. Natalia, S. Joan, K.R.P Arun, J.F. Oscar, O. Orlando, D. Roser, A.S. Karel, Z. Gullermo, Immunosuppresive Disease Poultry $1^{\text {st }}$ ed. Editorial Servet Publisher, USA, 2014.

[12] H.W. Brown, Dasar Patologi Klinis, Gramedia, Jakarta, 1979.

[13] Noeraini, Soebaktiningsih, L.E. Fitri, Pengaruh Ekstrak Biji Nimba (Azadirachta Indica) Terhadap Penurunan Derajat Parasit Dan Jumlah Hemozoin Pada Kultur Plasmodium Falciparum. Jurnal Kedokteran Brawijaya 10(3) (2004) 115-124.

[14] O.G. Mohammad amin, T.S. Qubih, Histphatology of virulent newcastle disease virus in immune broiler chicken treated with IMBO. Iraqi J. Vet. Sci. 25(1) (2011) 9-13.

[15] N.C. Jain, Essential of Veterinary hematology. Lea and Fibiger, Philadelphia. 1993. pp. 365-375.

[16] J.B. Sudiono, A. Kurniadhi, Hendrawan dan Djinantoro, Ilmu Patologi. EGC, Jakarta, 2003.

[17] M. Maung, T. Than, The pathology of human cerebral malaria. Amr. J. Trop. Med. Hyg, 43(2) (1989) $30-37$.

[18] M. Dkhill, Apoptotic changes induced in mice splenic tissue due to malaria infection. J. Microbial. Immunol. Infect. 42(1) (2009) 13-18.

[19] K.E. Schmidt, Analysis Of Parasite-Specific T Cells And Cellular Interactions In The Spleen During Plasmodium Berghei Induced Experimental Cerebral Malaria. Disertasi. University Of Bonn, German, 2011.

[20] N. Thawani, M. Tam, M.J. Bellemare, D.S. Bohle, M. Olivier, J.B. de Souza, M.M. Stevenson, Plasmodium Products Contribute to Severe Malarial Anemia by Inhibiting Erythropoietin-Induced Proliferation of Erythroid Precursors, J. Infec. Dis. 209(1) (2014) 140-149.

[21] A. Vazquez-Torres F.C Fang, Oxygen-dependent anti-Salmonella activity of macrophages. J. Trends Microbiol. 9(1) (2001) 29-33.

[22] Bratawidjaja. Imunologi Dasar $11^{\text {th }}$ ed., Balai Penerbit Fakultas Kedokteran UI, Jakarta, 2014.
[23] Y.T. Muladi, R.D. Siagian, R. Isnuwardana, Gambaran Jumlah Trombosit Pada Pasien Malaria Rawat Inap Di Rsud Abdul Wahab Sjahranie Samarinda Tahun 2010-2012. Fakultas Kedokteran Universitas Mulawarman Samarinda, 2004. 